[Jpn. J. Agric. Econ. Vol.19, pp.43-47, 2017]

\title{
Malaysian Muslim Consumers' Confidence in Purchasing Japanese Food Products in Selangor
}

\author{
Rika Terano $^{1,2 *}$ and Zainalabidin Mohamed $^{1}$
}

The mushrooming of Japanese restaurants and food manufacturers in Malaysia indicates a positive response among the Malaysians and the Muslims in particular. The main objective of this study is to understand Muslim consumers' confidence level on Japanese food and food products in Selangor, Malaysia. The study employed primary data collected from a total of 207 Muslim respondents selected and interviewed using structured questionnaire in Selangor. The findings identified 143 respondents with confident in purchasing Japanese Halal food products carrying Japanese Halal logo.

Key words: Japanese foods, confidence, Muslim consumer, Halal logo, Malaysia

\section{Introduction}

The retail industry has been one of the active sub-sector in the Malaysian economy. The Malaysian government opened the door to foreign retailers to invest in the country and thus, provided them the opportunity to enter the country's retail sector. The first foreign retail outlet established in the country was a Japanese based retail outlet, JUSCO in 1984, followed by Carrefour (French based) in 1994, TESCO (British based) in 2002, Giant Hyper/supermarket in 2003 (Hong Kong based) and AEON Big (Japanese based) in 2012. The recent acquisition of Carrefour Hypermarket by AEON Big in 2014 further expanded Japanese presence in the retail and food marketing sector. Besides the retail outlets, the influx of Japanese restaurants and handful of 5-star hotels are also witnessed in the country. However, most of the restaurants and food products do not display Halal Logo, notably the JAKIM Halal certification logo. Coming from Non-Muslim country, certain issues such as the uncertainties of Halalness of the products sold in retail outlets and restaurants have created dilemma among the Muslim consumers in their decision-making process. The importation of the products are permitted without consideration of their halal status, this has created doubt and loss of confidence in Japanese food products even though they might not contain Non-Halal ingredients. Nevertheless, the popularity of the Japanese foods among the Malaysian consumers in recent years cannot be overemphasized. As from 2009, the boom was brought about by Ramen, Teppanyaki, Sushi, and various franchise restaurants (JMA Consultants Inc., 2012).

Although Japanese products (non-food items) are not alien to Malaysians since the country's independence from the British, however, the Japanese foods and manufactured food products are quite new to the country. Japan being a nonMuslim country where previously there was no regulation guiding the Halalness of food and food products, the stigma of being non-Halal is always in the mind of the Muslim consumers since the food comes from a non-Muslim country. Even though Japanese foods are mostly fish and vegetable based, skepticism about the Halalness arise from the processing methods and ingredients used in the preparation of the foods. To ascertain the Halalness of food products in Malaysia, Muslim consumers pay more attention to the Halal logo. Since there is only one halal logo existing in the country under the Department of Islamic Development (JAKIM), the halal logo (Figure 1) has played an important role as a guidepost for confirming the Halalness of food products.

Due to the increasing number of imported foreign halal foods in Malaysia, various halal logos have started to appear in the retail stores.

Halal logos comes with food products from

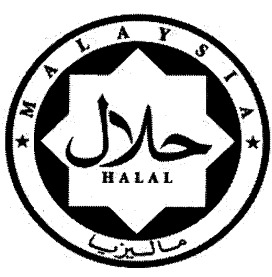

Figure 1. JAKIM

Halal logo in Malaysia

\footnotetext{
${ }^{1}$ Department of Agribusiness and Bi-Resource Economics, Faculty of Agricuture, Universiti Putra Malaysa

${ }^{2}$ Halal Products Research Institute, Universiti Putra Malaysia Corresponding author*: rika_t@upm.edu.my
} 
neighboring non-Muslim countries such as Thailand, Korea, Singapore, Taiwan, China, Australia, New Zealand and others. As at July 2010, there are 1,421 Japanese companies in Malaysia engaged in both manufacturing and nonmanufacturing sectors such as services, banking and so on (JETRO, 2011). Despite this, the number of active Japanese companies in the food and beverage production industry remain relatively small, with only 19 companies registered. The difficulties associated with obtaining Halal certificate limited display at the restaurants serving Japanese food to "pork-free" and "non-alcohol" logos. However, there are limited cases of companies such as Yakult, Ajinomoto and Kewpie companies which their products produced at local factories in Malaysia are certified by the Department of Islamic Development Malaysia and issued Halal certification and JAKIM Halal logo. For the products manufactured in Japan, JAKIM has recognized one of the Japanese Halal certificates issued by the Japan Halal Association in 2012 (Figure 2).

Most of the Japanese products and food provided at restaurants and market outlets are either without Halal certification (Halal Logo) or with logo under Japanese halal certification which limit potential markets in Malaysia especially among the Muslims. Muslim

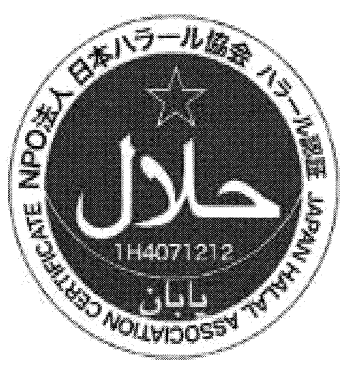

Figure 2. Halal logo of Japan Halal Association consumers will have no confidence in purchasing the products and thereby shy away from it. The research questions here arise: how confident are Malaysian Muslim consumers with regards to Japanese food in term of it Halalness. The Muslim consumers rely mainly on the Halal Logo displayed at restaurants or on food packaging in making food choice decision. Therefore, understanding consumers' confidence level with regards to the Japanese food will give some ideas on the consumption pattern, taste and preferences and provide information about important factors that could enhance the patron of Muslims in Japanese restaurant serving Japanese food and Japanese manufactured food products in the hyper and supermarket. This will help the Japanese food industry to improve their marketing strategies in Malaysia.

\section{Literature Review}

Many studies have been conducted all over the world regarding food choice and preferences as well as about the Halalness of food products among the Muslim consumers. Muslim customers are very much concerned about the authenticity of the Halalness of the food products claimed by food suppliers and manufacturers. Halal brands, trademarks, and logos sometimes hold no reliability or authenticity leading to possible doubts from the customers (Firdaus, 2013). Mohayidin and Kamarulzaman (2014) found that important product attributes such as Halal certification have an influence on consumers' preferences and purchasing behaviors. A studied by Golnaz et al., (2012) found that socio-economic/demographic characteristics and attitudinal factors influenced the respondents' opinions and confidence in Halal labeled food products. In general, various socioeconomic/demographic and attitudinal characteristics were found to significantly influence the likelihood of the respondents' degree of confidence in the "Halalness" of manufactured food products that carry the Halal logo. The older generation particularly the rural folk and those with higher education level and higher level of religiosity are likely to be less confident in the Halal labeled food products from foreign countries.

Furthermore, the study also showed that Muslim consumers, in particular, rely on Halal logo displayed on food packages or backdrop of the restaurants in gauging the Halalness of the food or food products. That is, with the Halal logo the Muslim consumers have confidence that the food or food products are Halal (Golnaz et al., 2012). In the same token considering the effect of the Halal logo on food labels, it was revealed that consumers are very concerned about Halal food and the logo on food products (Golnaz et al., 2009). In order to increase awareness and knowledge about Japanese food, food fairs are usually organized in various places which provide avenues to showcase local Japanese foods and food products. For instance AEON (previously called Jusco) hypermarket, ISETAN, and others Japanese food companies organized their own food fair to attract consumers to their stalls as well as to promote Japanese foods. In addition to Japanese food fair at AEON and Mid-valley driven by private companies such as Japanese Food Fair 2015 in Sabah, the WASHOKU-Try Japan's Good Food was organized by the Ministry of Agriculture, Forestry, and Fisheries in Kuala Lumpur Food Fair 2015. Zainalabidin et al. (2013) noted that Muslim consumers are sensitive to any 
false information as it will reduce their confidence level which may subsequently affect their intended purchasing decisions. Food preference and choice are not only influenced by taste or flavour of the food but also the confidence level in the Halalness of the foods among the Muslim consumers. Therefore, it is a very important issue that needs to be addressed because Muslim consumers ascertain the Halalness of food products sold in the market based on the ingredients labeling and the Halal logo that accompany it. The consumption of Food from non-Muslim countries will be subjected to skepticism or even prohibited if there is no evidence showing the Halalness of the products.

\section{Methodology}

The study collected information related to consumers' confidence in purchasing Japanese manufactured food and eating at Japanese restaurants. A total of 207 Muslim respondents were selected and interviewed using structured questionnaire. There are advents of greater numbers of Japanese food restaurants and availability of Japanese manufactured food products in urban and sub-urban areas. The shopping complexes and hotels with Japanese food restaurants serve as an appropriate location for data collection. Thus, the survey was conducted in the shopping complexes where Japanese restaurants are well represented. Selangor has the most number of modern shopping complexes with Japanese restaurants as one of the food outlets and therefore was chosen as the study area. Systematic random sampling technique was used to select every five shoppers as possible respondents. The questionnaire consisted of three sections, the first section collected information about respondents' socio-demographic characteristics, the second section gathered attitudinal characteristics of the Muslims with regards to Japanese food preferences and the last section gauged consumers' awareness of the Halalness of Japanese food and food products and their intention to patron Japanese restaurants or purchase Japanese manufactured food products with information regarding the collaboration between Japanese Halal certification body and JAKIM.

Descriptive analysis was used to describe respondents' demographic profiles followed by correlation analysis and binary logistic regression. Given the information on the collaboration between the Japanese Halal certification body and JAKIM in the binary logistic regression, Y represents "consumer with confidence in purchasing Japanese food products" coded as one and "no confidence in purchasing
Japanese food products" coded as zero. The equation for the logit model is shown as follows:

$\operatorname{Logit}(\mathrm{Y})=$ natural $\log ($ odds $)=\ln (\pi / 1-\pi)=\alpha+\beta \mathrm{X} ;$...eq.(1) Where:

$-Y$ is being confidence in purchasing Japanese food products and to eat at Japanese restaurant; $0=\mathrm{No}, 1=\mathrm{Yes}$, and

$-\mathrm{X}_{1}$ is the respondents' gender; $0=$ female, $1=$ male,

$-\mathrm{X}_{2}$ is the respondents' education level; $1=$ above tertiary, 0 $=$ below tertiary,

$-\mathrm{X}_{3}$ is the respondents' age; $0=$ above 30 years old, $1=$ below 30 years old,

$-\mathrm{X}_{4}$ is the average number of foreign halal logos recognized in Malaysia; 0 = below 3 logos, 1 = above 3 logos

$-\mathrm{X}_{5}$ is the respondents' answer: do you know there is a collaboration between Japanese Halal certificate body and JAKIM in Malaysia? ; $0=$ No, $1=$ Yes,

$-\mathrm{X}_{6}$ is respondents' answer: do you know there are certification bodies existing in Japan? ; $0=$ No, $1=$ Yes, and

$-\mathrm{X}_{7}$ is respondents' answer: do you recognize Japanese Halal logo? ; $0=$ No, $1=$ Yes.

\section{Results and Discussions}

Results of the demographic profile of respondents are shown in Table 1. Out of the 207 respondents interviewed, females were 146 and males were 61 . More than half of the respondents (127 people) are in the range of 18 to 29 years old, 47 respondents are within 30 to 49 years old and 33 respondents are older than 50 years old. The majority of the respondents have completed secondary school.

Table 1. Demographic profile of the respondents

\begin{tabular}{lcc}
\hline Demographic profile & & $\begin{array}{l}\text { No. of } \\
\text { respondents }\end{array}$ \\
\hline Gender & Male & 61 \\
& Female & 146 \\
Age & $18-29$ & 127 \\
& $30-49$ & 47 \\
Education & 50 's above & 33 \\
& Until secondary & 40 \\
& school & \\
& After Secondary & 167 \\
\hline
\end{tabular}

Source: Own survey, 2015

Figure 3 shows the Halal logo which can be recognized by the respondents with regards to the country of origin. Four halal logos were ranked in the top four among other logos. These were logos from Thailand, Singapore, Indonesia and 
of course JAKIM Halal logo which is the most recognized in Malaysia.
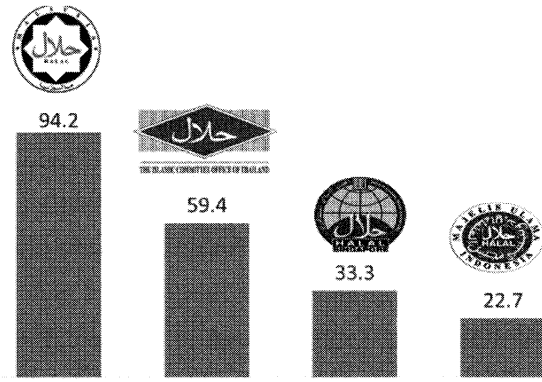

Figure 3. Foreign Halal Logo recognized by the respondents (\%)

Source: Own survey, 2015

As shown in Table 2, among the 207 respondents surveyed in the study, 69 respondents were aware of the collaboration between Japanese Halal certificate body and Malaysia JAKIM, while 138 respondents were not aware of it. In term of multiple existences of halal certification bodies in Japan, only 81 respondents were aware that there are few Halal certification bodies existing in Japan while more than half of the respondents (126 people) were not aware of their existence. This shows that awareness about the Halal logo, certification bodies and collaboration with JAKIM in Malaysia are below expectation since less than half of the respondents are aware of them. While only 86 respondents are aware of the Japanese Halal logo, there are 143 respondents who were identified as consumers with confidence in purchasing Japanese halal food products with Japanese halal logo.

Table 2. Attitudinal characteristics of the respondents towards Japanese Halal logo

\begin{tabular}{lr}
\hline Questions & No. of respondents \\
\hline Do you know there is a collaboration between Japanese Halal \\
certification body and JAKIM in Malaysia? \\
Yes & 69 \\
No & 138
\end{tabular}

Do you recognize there are few certificate bodies existing in Japan?

Yes

No

Do you recognize Japanese Halal logo?

Yes

No

If you see Japanese Halal certificate on food products, will you be confidence in purchasing the food products?

Yes

No
A binary logistic regression was used to determine the main factors influencing Malaysian Muslim consumers' confidence level in purchasing Japanese food products. As shown in Table 3, the correlation between variables was tested to avoid multicollinearity. Due to the relatively high correlation $(0.59)$ between collaboration $\left(\mathrm{X}_{5}\right)$ and awareness towards Japanese Halal logo $\left(\mathrm{X}_{7}\right), \mathrm{X}_{7}$ was removed from the model to avoid multicollinearity. There was no strong correlation among the rest of variables $\left(\mathrm{X}_{1}-\mathrm{X}_{6}\right)$.

Table 3. Correlation matrix between the

variables to be used in the regression model

\begin{tabular}{lccccccc}
\hline & 1 & 2 & 3 & 4 & 5 & 6 & 7 \\
\hline 1. Gender & 1 & & & & & & \\
2. Education & -0.20 & 1 & & & & & \\
3. Age & -0.34 & 0.45 & 1 & & & & \\
$\begin{array}{l}\text { 4. No. of foreign halal } \\
\text { logos recognize }\end{array}$ & 0.02 & -0.32 & -0.32 & 1 & & & \\
$\begin{array}{l}\text { 5. Collaboration } \\
\text { 6. Few certification }\end{array}$ & 0.24 & 0.028 & -0.16 & -0.12 & 1 & & \\
$\begin{array}{l}\text { bodies } \\
\text { 7. Do you recognize }\end{array}$ & 0.11 & -0.22 & -0.18 & 0.15 & 0.06 & 1 & \\
Japanese Halal logo? & 0.122 & 0.133 & 0.00 & -0.20 & 0.59 & 0.07 & 1 \\
\hline
\end{tabular}

Note: The number 1 to 7 are corresponding to $X_{1}$ to $X_{7}$ in eq.(1)

Source: Own survey, 2015

The estimated coefficients and the statistical significance levels for the logistic regression are shown in Table 4. The result of the binary logistic regression indicates that three of the variables are statistically significant with positive signs. There are six variables representing the demographic profile such as gender, education, age and attitudinal characteristics of the respondents in terms of the number of foreign halal logos recognized, collaboration between Japanese Halal certification body and JAKIM and few certificate bodies in Japan. Among the demographic profile of the respondents, age was an important determinant of consumers' confidence level in purchasing Japanese food products with a positive sign. This finding reveals that consumers especially those below 30 years of age are 2.054 times more likely to be confident in purchasing Japanese food products compared to older consumers. In addition to age, respondents' recognition of the collaboration between JAKIM and Japanese Halal certificates was also found to be an important factor influencing consumers' confidence towards purchasing Japanese food products. The respondents who are aware of the collaboration between Japanese halal logo and JAKIM are 3.982 times more confident in purchasing Japanese food products compared to the respondents who are not aware of the collaboration. Also, those respondents who recognize the

Source: Own survey, 2015 
existence of multiple Japanese halal logos and are aware of them on the food products are 3.621 times more likely to be confident in purchasing Japanese food products than the rest.

\section{Table 4. Results of binary logistic regression for consumers' confidence level in purchasing Japanese food product}

\begin{tabular}{|c|c|c|c|c|c|c|}
\hline & $\mathrm{B}$ & S.E. & Wald & $\mathrm{Sig}$ & & $\operatorname{Exp}(B)$ \\
\hline Gender & 0.164 & 0.394 & 0.174 & 0.677 & & 0.848 \\
\hline Education & 0.009 & 0.509 & 0.000 & 0.985 & & 0.991 \\
\hline Age & 0.720 & 0.399 & 3.258 & 0.071 & $*$ & 2.054 \\
\hline $\begin{array}{l}\text { No. of foreign } \\
\text { halal logos } \\
\text { recognize }\end{array}$ & 0.892 & 0.477 & 3.492 & 0.062 & $*$ & 2.439 \\
\hline Collaboration & 1.382 & 0.404 & 11.692 & 0.001 & $* * *$ & 3.982 \\
\hline $\begin{array}{l}\text { Few } \\
\text { certification }\end{array}$ & 1.287 & 0.379 & 11.509 & 0.001 & $* * *$ & 3.621 \\
\hline Constant & 0.552 & 0.526 & 1.102 & 0.294 & & 0.576 \\
\hline
\end{tabular}

Source: Own survey, 2015

Note: $* * *$ denotes $1 \%$ level of significance

* denotes $10 \%$ level of significance

Hosmer and Lemeshow test Chi-square $=0.55$ (Sig. 0.540)

\section{Conclusion}

This study clarifies the characteristics of Muslim consumers with regards to their confidence level in purchasing Japanese Halal products with Japanese Halal logo certification in Selangor, Malaysia. More than half of the respondents were confident of the Japanese Halal logo and will purchase Japanese food products (mainly with Japanese Halal logo). The results also indicated that few respondents were aware of the collaboration between Japanese Halal certification bodies and JAKIM in Malaysia. Many of the respondents are not aware of the existence of multiple halal certification bodies in Japan. Nevertheless, this response has played an important role in their confidence level towards purchasing Japanese food products.

For the manufacturers, marketers, and retailers of Halal food products in Japan, it is important to understand whether Muslim consumers in Muslim countries recognize the Halal logo from Japan and have confident in purchasing the products with such Japanese Halal logo. Understanding the determinants of Muslim consumers' confidence will help not only Japanese food manufacturers and marketer but also other non-Muslim foreign players in the food sector to further promote their product in the Muslim consumer markets.

\section{References}

Firdaus, A., A. A. Abang Zainoren, and H. Jamil, (2013) The Dimensions of Customer Preference in the Foodservice Industry, Business: Theory and Practice Verslas: Teorija Ir Praktika14 (1): 64-73.

Golnaz, R., M. Zainalabidin, S. Mad Nasir, and F. C. Eddie-Chew (2009) Concern of Halalness of Halal-Labelled Food Product among Muslim Consumer in Malaysia. Evaluation Selected Demographic Factors, Economic and Technology Management Review 4: 65-73.

Golnaz, R., M. Zainalabidin, and S. Mad Nasir (2012) Assessment of Consumers' Confidence on Halal Labelled Manufactured Food in Malaysia, Social, Science. \& Humanities 20 (1): 33-42. JETRO (2011) Japanese related company list retrieved from https://www.jetro.go.jp/ext_images/malaysia/services/jpncoinm sia/index.html/JRC_Statistic.pdf

JMA Consultants Inc (2012) Retrieved from http://www.jmac.co.jp/ Mohayidin, M. G, and Kamarulzaman, N. H. (2014) Consumers' Preferences toward Attributes of Manufactured Halal Food Products, Journal of International Food \& Agribusiness Marketing 26 (2): 125-139.

Zainalabidin, M., S. Mad Nasir and R. Golnaz (2013) The Effect of Possessing Information about Halal Logo on Consumer Confidence in Malaysia, Journal of International Food \& Agribusiness Marketing 25(Sup1): 73-86. 